REVIJA ZA ELEMENTARNO IZOBRAŽEVANJE

JOURNAL OF ELEMENTARY EDUCATION

Vol. 12, No. 4, pp. 291-314, December 2019

\title{
EX'TENSIVE READING AND CHANGES TO READING MOTIVATION IN EFL AMONG SLOVENE PRIMARY SCHOOL PUPILS
}

\author{
ANJA PIRIH
}

Potrieno/Accepted

5. 11. 2019

Objavljeno/Published

9. 12. 2019

\section{Keywords:}

EFL, changes to reading motivation, extensive reading, primary school pupils, influences on EFL reading motivation

\section{Ključne besede:} tuji jezik angleščina, spremembe $\mathrm{v}$ bralni motivaciji, ekstenzivno branje, osnovnošolci, vpliv na bralno motivacijo $\mathrm{v}$ angleščini

\section{UDK/UDC}

028:373.3:811.111'243

\author{
University of Primorska, Faculty of Humanities, Slovenia \\ CORRESPONDING AUTHOR/ KORESPONDENČNI AVTOR \\ anja.pirih@fhs.upr.si
}

\begin{abstract}
Povzetek The article provides insight into the dynamics of the EFL reading motivation of a group of Slovene primary school pupils voluntarily participating in a 9-month pilot extensive reading programme in EFL and the factors causing motivational changes. Analysis of the semi-structured interviews and book reports confirms that reading motivation in EFL is a complex and dynamic process fuelled by numerous influences, most noticeably reading materials, the influence of family members, positive attitudes towards English, and external demands, which needs to be considered when designing reading programmes and researching reading motivation.
\end{abstract}

\section{Ekstenzivno branje in spremembe $\mathrm{v}$ bralni motivaciji $\mathrm{v}$ angleščini kot tujem jeziku pri slovenskih osnovnošolcih}

Članek predstavlja ugotovitve, pridobljene na osnovi raziskave o dinamiki bralne motivacije $\mathrm{v}$ angleščini kot tujem jeziku pri skupini slovenskih osnovnošolcev, ki so se prostovoljno vključili $\mathrm{v}$ 9-mesečni pilotni program ekstenzivnega branja $\mathrm{v}$ angleščini, in vzroke za spremembe v njihovi motivaciji. Analiza polstrukturiranih intervjujev in bralnih poročil je potrdila, da je bralna motivacija v angleščini kot tujem jeziku kompleksen in dinamičen proces, na katerega vplivajo predvsem bralna gradiva, družina, pozitivna stališča do angleškega jezika in zunanje obveznosti, vse to pa je treba upoštevati pri oblikovanju bralnih programov in prihodnjih raziskavah bralne motivacije. 


\section{Introduction}

One of the most important factors determining academic achievement among students of different ages and in different cultural contexts is reading achievement, which is shaped by various environmental and personal factors, most noticeably reading motivation (Guthrie \& Wigfield, 1997; Pečjak \& Košir, 2004; Pečjak \& Peklaj, 2006). Experts in the field of reading (Baker \& Wigfield, 1999; Guthrie \& Wigfield, 1997; Pečjak \& Gradišar, 2012) see reading motivation as one of the key factors that influence reading efficiency and learning motivation in general. In the field of foreign language (FL) learning, reading motivation plays an important part, influencing the development of linguistic skills as well as attitudes towards FL, FL learning and reading. Even though young Slovene teenagers often choose reading materials in English for their voluntary free-time reading (Pirih, 2015), the field of reading motivation in a foreign language is under-researched in the Slovene context. In Slovene primary schools, reading in a foreign language is in most cases limited to intensive reading (e.g. skimming a text for specific information to answer true or false statements, scanning a text to match headings to paragraphs), and the pupils hardly ever get the opportunity to participate in extensive reading activities (e.g. quiet reading time or a reading breakfast), even though extensive reading has been recognised as a very effective way of teaching and promoting second language (L2) or FL reading. Numerous studies (e.g. Mason \& Krashen, 1997; Leung, 2002; de Morgado, 2009) have shown its linguistic and affective benefits, and it has been incorporated into various L2/FL reading programmes worldwide. For a number of FL reading motivation studies, an extensive reading programme represents a suitable research context, since its components reflect the widely used FL reading motivation model by Day and Bamford (1998). However, the majority of existing studies on EFL reading motivation (e.g. Baker \& Wigfield, 1999; Guthrie \& Wigfield, 1997; Mori, 2002; Takase, 2007; Judge, 2011) have failed to consider more recent findings in the field of FL learning motivation and reading behaviour, namely the dynamic nature of FL learning motivation (Dörnyei and Otto, 1998) and the temporal aspect in $\mathrm{L} 2$ reading motivation, as well as digital reading, which has become an integral part of daily life and education worldwide. The aim of this research was therefore to involve a group of Slovene primary school pupils in an extensive reading programme in EFL with complete autonomy in choosing their 
reading materials and thus to gain insight into the dynamics of their EFL reading motivation and the factors causing any motivational changes that might occur.

\section{(FL) reading motivation}

Researchers of reading motivation define it as a multidimensional construct with various goals and beliefs, which not only influences the individual's reading behaviour (Pečjak \& Gradišar, 2012) but also functions as the most important component of literacy and a starting point for one's reading literacy. As Pečjak and associates (2006) explain, an individual's reading motivation is influenced by numerous external factors and changes in the course of his/her life, which makes research into reading motivation a challenging task.

The theoretical framework for researching the dimensions of reading motivation can be found in self-efficacy theory (Bandura, 1993), achievement goal theory (Ames, 1992) and most of all, Deci and Ryan's (1985) self-determination theory. Deci and Ryan (1987) proposed four dimensions of motivation: competency, relatedness, autonomy and interest. These were further analysed by Wigfield and Guthrie (1997) in their Motivation for Reading Questionnaire (MRQ). The MRQ was administered to a sample of elementary school learners in the USA, and the results confirmed that children's reading motivation is multidimensional, more specifically, composed of 11 dimensions of reading motivation that form three categories: competence and self-efficacy beliefs, purpose for reading / reading goals and the social aspects of reading. According to Wigfield and Guthrie, students who believe in high reading self-efficacy and see reading material as challenging fulfil their need for competence, which facilitates their intrinsic motivation. However, not all individuals with high reading self-efficacy become engaged readers. For students to engage in reading, the reading task should also be interesting, meaningful (the achievement of the reading task should have some personal value for them) and useful (Wigfield, 1997). This is closely linked to the purposes that students have for reading and their intrinsic and extrinsic motivation. As Wigfield and Guthrie (1997) explain, to develop students' intrinsic motivation for reading, it is crucial that they get involved in reading, that they read about topics that interest them, and that they perceive reading as important for their lives and/or success. On the other hand, extrinsically motivated students are interested in reading if the 
reading tasks bring rewards (public acknowledgement / recognition or grades) or help them outperform others (competition). Extrinsic motivation comes from external, social sources and usually results in less cognitive engagement and the use of less complex learning strategies (Ryan \& Deci, 2000). Wigfield and Guthrie's MRQ study (ibid.) showed that intrinsic motivation more than other factors facilitates readers' engagement in reading, which is crucial for lifelong, voluntary reading and has long-term effects. Reading is, of course, also a social activity, since it takes place in social settings and makes it possible for the readers to achieve social goals. Research has shown that active and good readers come from families that value books, encourage reading and participate in reading. The sense of relatedness that children acquire in such families plays an important role in their interest in reading: i.e. they are drawn to the activity that is meaningful to others in their closest social environment (Sweet, 1997).

In the context of second / foreign language reading, the most influential reading motivation model was designed by Day and Bamford (1998) and tries to explain the factors influencing one's decision to read in a second language within the expectancy - value theory of L2 learning motivation. According to this theory, achievement behaviour is influenced by two key factors: the individual's expectation of success in a given task and the value the individual associates with success in that task (Eccles et al., 1983; Eccles \& Wigfield, 1995). Applying expectancy - value theory to reading motivation, Day and Bamford (1998) developed a L2/FL reading motivation model that consists of four major components: a) materials, b) reading ability in L2 (both related to the expectancy component of successful L2 reading), c) attitudes toward reading in L2, and d) sociocultural environment (both related to the value component). According to Day and Bamford (1998, 2002), reading materials need to be interesting, attractive, readily available and easy to understand (well within the learners' reading competence in the foreign language). Reading ability in L2 relates to the individual's sense of self-efficacy and beliefs about their reading ability in L2. Students with low reading ability are likely to have low expectations of success, and as a result, they tend to have lower motivation to read, and vice versa. For Day and Bamford, the factors crucial for shaping L2 reading attitudes are L1 reading attitudes, previous L2 reading attitudes (if any), attitudes toward L2, culture and people, and the L2 classroom environment. Even though 
they claim that positive and negative attitudes to L1 transfer to L2 reading, there are several studies (among them Yamashita, 2004; Takase, 2007; and Pirih, 2015) which show that the transfer of reading attitudes is more complex and not nearly as straightforward as that. The same is true for previous L2 reading attitudes, which presumably generate reading attitudes in another foreign language. Moreover, Day and Bamford (1998) believe that favourable feelings towards the second/foreign language, culture and people, as well as the classroom environment (the language teacher, classmates, materials, activities, etc.) may transfer to reading in L2. The last important influence is the learner's sociocultural environment, which includes the impact of significant others, namely family and friends. In Day and Bamford's (1998) opinion, motivating reading materials and positive attitudes towards reading in L2 have a stronger influence on L2 reading motivation and can compensate for low reading ability and/or an unsupportive sociocultural environment (1998). However, studies (Fujita \& Noro, 2009; Sani \& Zain, 2011) have found the crucial role that L2 proficiency and L2 reading ability play in L2 reading motivation, while de Burgh-Hirabe (2011) also identified a less favourable sociocultural environment as a decisive factor in hindering students' L2 reading motivation. Nevertheless, Day and Bamford's model remains the dominant theoretical framework for research in the field of L2 reading motivation, which is mostly studied in close connection with extensive reading in a foreign language (Takase, 2007; Nishino, 2007; Judge, 2011; de Burgh-Hirabe \& Feryok, 2013), an effective strategy for motivating L2 learners (Day \& Bamford, 1998, 2002).

\section{Extensive reading}

Extensive reading (ER), sometimes referred to as sustained silent reading (McCracken, 1971, p. 521) or free voluntary reading (Krashen, 2011), is not only a style of reading (alongside skimming, scanning and intensive reading), but reading with a distinct pedagogical potential, in Day and Bamford's words "real-world reading but for a pedagogical purpose" (1998, p. 4). The term was first used by Harold Palmer (1968), who defined it as reading "book after book" (p. 137) with the reader's attention on the meaning, not the language, of the text. He was also the first to contrast it with intensive reading, which refers to the close study of shorter passages, accompanied by various linguistic tasks. This type of reading is seen as a 
language lesson rather than a reading lesson (Alderson \& Urquhart, 1984, p. 246), while ER replicates real-life informative and pleasurable reading of large quantities of reading material that learners select themselves (Day \& Bamford, 1998; Grabe \& Stoller, 2002).

The complexity of the ER approach is perhaps most evident in the description of its characteristics that Day and Bamford (2002) compiled in the form of the Top Ten Principles for Teaching Extensive Reading, in which the authors focused on the reading materials, the reading process, the role of the learner, and the role of the teacher:

1. The reading material is easy.

2. A variety of reading material on a wide range of topics must be available.

3. Learners choose what they want to read.

4. Learners read as much as possible.

5. The purpose of reading is usually related to pleasure, information, and general understanding.

6. Reading is its own reward.

7. Reading speed is usually faster rather than slower.

8. Reading is individual and silent.

9. Teachers orient and guide their students.

10. The teacher is a role model of a reader.

For ER to succeed, the reader must have access to a variety of easy reading material on a wide range of topics. As Day and Bamford explain, this not only encourages reading in general, but enables a flexible approach to reading, with learners reading for different reasons (to find information, to pass the time, to enjoy themselves, etc.) and in different ways. Not only should diverse, reading material for ER be easy as well, meaning it should be well within the learners' reading competence, at $i$ minus 1 level (i being the level of reader's linguistic ability). If the text is too demanding linguistically, this interrupts the flow of reading and forces learners into dictionary use, which further moves the reading experience away from reading for pleasure towards intensive reading. It is therefore crucial that learners start with easy materials and avoid the use of dictionaries. 
Day and Bamford (2002, p. 138) state that the goal of ER is "related to pleasure, information and general understanding" and that "reading is its own reward," putting in focus the reader's personal experience. The reader is autonomous in choosing the reading materials, their level, and the time and pace of reading, while being encouraged to stop reading anything that might be too difficult or not interesting enough. This principle gives the readers control of and responsibility for their own learning: i.e., it emphasizes self-directed learning, which fosters intrinsic motivation, develops language proficiency and increases self-esteem (Dickinson, 1995).

Day and Bamford (ibid.) further describe ER as an individual and silent activity, in which the teacher's role is that of mentor and role model. Teachers should not only explain the methodology, assist in selecting appropriate texts, point out the expected outcomes and encourage students to read as widely as possible, but also share the reading experience with their students and teach the attitudes and behaviours of a reader by being readers themselves. As discussed by Bratož and Žefran (2018), the classroom environment offers plenty of opportunities for enhancing both teacher-learner and learner-learner interaction. In the context of $\mathrm{ER}$, this is essential in creating a class reading community.

Relatively fast reading speed seems only natural when one reads interesting and easily understandable reading materials. Nuttall (in Day \& Bamford, 2002) closely links reading speed to enjoyment and comprehension in the "vicious circle of the weak reader: Reads slowly; Doesn't enjoy reading; Doesn't read much; Doesn't understand; Reads slowly..." and "the virtuous circle of the good reader: Reads faster; Reads more; Understands better; Enjoys reading; Reads faster...” (p. 138). The principle that raises many questions and is included in the 'vicious' as well as 'virtuous' circle, is the amount of reading. According to Day and Bamford (1998), as students differ in their circumstances and abilities, so does the quantity of materials and the time they spend reading. Nevertheless, they set the lower limit of their reading target at one book (the length depends on the reading ability) a week (Day \& Bamford, 2002). The amount of time this takes also depends on how long the students can read with pleasure before losing interest. The danger that Day and Bamford (1998) see in setting reading quotas is that it might diminish reading 
enjoyment and reduce reading to a number of pages or an amount of time spent reading per week.

One of the most debated components of ER programmes is the reading materials. Many researchers (Day \& Bamford, 1998; Mori, 2002; Hidi \& Renninger, 2006; Lien, 2010; Lake, 2014) see these as crucial in maintaining the interest and reading motivation of students. However, when it comes to the question of authenticity vs simplicity, the ER specialists remain divided. In a typical extensive reading programme, learners are offered / instructed to read language learner literature, most commonly graded readers. Graded readers are designed to suit different proficiency levels, thus enabling the readers to choose texts within their reading comfort zone and developing their L2 reading fluency and confidence. On the other hand, many language teachers see authentic, real-life texts as relevant, motivating, culturally enlightening and as genuine discourse that prepares students for realworld reading. Additionally, readers in several studies (e.g. Nishino, 2007; Aiello, 2016) expressed strong preference for authentic L2 texts over graded readers. In their attempt to re-examine authenticity and simplicity of reading materials, Day and Bamford (1998) point out that ER instructors should not select texts solely on the basis of the target audience or source, the level of language, the complexity of syntax, etc., but based also on the natural qualities of a text that make it authentic. In their opinion, a variety of interesting and attractive materials, suitable for ER, includes not only language learner literature, but also children's books, learners' own stories, varied types of newspapers (tabloid, quality), magazines, popular and simple literature, young adult literature, comics and translations. Language learner literature, however, is seen as the first choice for beginner and intermediate students, since it allows them to progress slowly and develop reading fluency (Day \& Bamford, 1998). Another materials-related issue that divides the reading instructors is the medium of the text. Should readers be offered paper-based or screen-based reading materials? In recent decades, the increased use of the internet and smartphones has changed, among other things, the reading behaviour of the majority of the population, most noticeably teenagers and young adults. They use the internet for a variety of purposes, academic and personal, and consequently, a certain amount of reading has already moved into the virtual world. Especially when reading in English, students find most of their reading materials online (Pirih, 2015), 
and screen-based reading is increasingly being used in educational contexts as well. ER programmes have also started turning to online materials to offer a wider selection of (authentic) texts on a virtually unlimited range of topics and genres. The internet as a source of reading materials is especially valuable for foreign language teaching/learning, since obtaining a wider range of printed materials in the target language often represents a considerable cost and may impede the implementation of an extensive reading programme (Robb and Susser 1990). Even though researchers (Mangen, Walgermo \& Brønnich, 2013; Milliner \& Cote, 2015; Takase, 2016) point to some of the downsides of screen-based reading, i.e. lower reading rates, lower comprehension rates, not as deep engagement with a text as in paper-based reading, other studies (Mangen \& Van der Weel, 2016; Walker, 2017) show the growing preference of students for screen-based reading and stress its powerful pedagogical potential, especially easy access to varied, up-to-date sources, development of students' time management skills and their autonomy (Silva, 2009).

\section{Research on extensive reading and FL reading motivation}

Numerous researchers have investigated ER and its (positive) influence on very different aspects of L2 learning and, more specifically, on reading motivation. A substantial body of research has studied the impact of ER on reading motivation among adults and university students (among them Mason \& Krashen, 1997; Leung, 2002; de Morgado, 2009; Judge, 2011), and several studies have focused on primary and secondary school readers. In their meta-analysis, Briggs and Walter (2016) gathered 30 studies on ER and young L2 learners' motivation and attitudes and showed the positive impact that extensive reading has on $\mathrm{L} 2$ reading motivation and attitudes. Moreover, they identified the factors that make the most difference in $\mathrm{L} 2$ reading motivation and attitudes: $\mathrm{L} 2$ reading proficiency, pre-ER attitudes towards L2 reading, L2 reading material, the interplay between L2 text readability and $\mathrm{L} 2$ reading proficiency, autonomy, and time/external work constraints. 
During lengthy learning processes, such as in L2 learning and ER, attention has been drawn to the unstable nature of motivation. Dörnyei and Otto (1998, p. 45) claim that "motivation is not so much a relatively constant state but rather a more dynamic entity that changes in time". Recognition of changes in motivation over time has led to process-oriented approaches to the analysis of L2 motivation research, which identified multiple phases fuelled by largely different internal and contextual motives (ibid.). However, hardly any studies (Nishino, 2007; de BurghHirabe, 2011; de Burgh-Hirabe and Feryok, 2013) have investigated ER over longer time periods and explored the temporal aspect in L2 reading motivation. Their major finding is that L2 reading motivation is indeed complex and dynamic; it is influenced by multiple separate factors, which change over time. Nishino (2007) researched motivational change over 2.5 years of ER by two younger EFL students in Japan. Data was collected from semi-structured interviews and field notes taken during the reading sessions, and the results confirmed that $\mathrm{L} 2$ reading motivation is not static but a dynamic process that changes over time. Nishino especially stressed the importance of reading interesting books at the appropriate level of proficiency to build confidence and the feeling of achievement. Her students reported less interest in graded readers and a preference for authentic texts, while their motivation was also influenced by the pleasure and flow of reading, their tendency towards more independent reading, and entrance exams. De BurghHirabe and Feryok's qualitative study (2013) set out to research motivational changes for ER in Japanese as a foreign language by using de Burgh-Hirabe's (2011) model of the complex and dynamic nature of L2 motivation, designed in accordance with Dörnyei and Ottó's process model of L2 motivation (1998) and Day and Bamford's model for ER (1998). The authors conducted interviews and collected journal entries from the participants, who read only graded readers outside of class and participated in the programme voluntarily. Ten factors influencing their reading motivation were identified: a) the goal of improving their Japanese, b) instrumental benefits, c) perceived progress and a feeling of success, d) intrinsic values, e) ER books, f) beliefs about L2 reading, g) autonomy, h) external demands, i) distractions and j) self-regulation. According to de Burgh-Hirabe and Feryok's (2013) model, the first two factors relate to the project preactional phase (which concerns the decision to participate in the ER project), while the other factors relate to the project actional phase (which concerns each book-reading experience within 
the project) and the postactional phase (which concerns the evaluation of the ER project).

In Slovenia, the use of ER activities in the L2/FL classroom is not an established practice, apart from the Reading Badge projects, which, however, require elementary school participants to read only a few externally selected graded readers in total. Therefore, the potential of this pedagogical approach to FL reading instruction in Slovenia has not yet been exploited or researched. With this in mind, the author implemented a 9-month ER programme at one of the Slovene primary schools and researched the students' perceptions of EFL extensive reading, changes in their motivation to read extensively over the course of the programme and factors influencing these changes.

\section{Study and results}

Slovene young teenagers do voluntarily read in English in their free time (Pirih 2015); however, they are seldom if ever introduced to a structured ER approach when learning second or foreign languages at school. To give them an opportunity to participate in an ER programme and evaluate its pedagogical potential, such a programme was implemented at a Slovene primary school, and some of the most important characteristics were researched. Unlike most ER programmes with primary school pupils as participants, this programme was implemented outside the school curriculum, as a voluntary extracurricular activity, and the participants were given complete autonomy in choosing their reading materials. They were not limited to reading graded readers or other language learner texts, nor to reading only printed materials. They read in their free time, independently choosing the time, place and pace of their reading. For this reason, special attention was given to evaluating reading materials, the reading process, and linguistic and affective benefits that the participants reported experiencing (Pirih 2017). The results of the evaluation study suggest that ER can be used as an effective pedagogical approach for teaching EFL reading, not only for secondary school and university students, but for older primary school students as well, since the young readers reported linguistic and affective benefits, as well as increased reading motivation in EFL. They expressed a preference for authentic materials over graded readers and 
developed a degree of independence in selecting interesting reading materials at an appropriate difficulty level (Pirih ibid.). Moreover, the ER programme provided the context for the current qualitative research into the temporal aspect of reading motivation in EFL, as well as the changes in and causes of these changes. The present study therefore focuses on the following research questions:

1. Did the motivation to read extensively in EFL among participants in the extensive reading programme change over the course of the programme?

2. What were the factors influencing the possible changes in their EFL reading motivation?

\section{Participants}

After some initial changes in the number of the participants, the final case study group included 10 students (8 girls and 2 boys) aged 13-14, from a semi-urban primary school in Slovenia. Prior to the start of the ER programme, which they joined voluntarily, the participants had received at least five years of formal English education (at least 350 hours); two students attended additional English lessons at private language schools, two students had travelled to English speaking countries. The group was very heterogeneous, with different English (reading) proficiency levels. The names used for them in this paper are pseudonyms.

\section{Data collection and analysis}

Self-report data that were used in this study were collected using a combination of quantitative and qualitative methods. The most important source came from five short, semi-structured interviews (approximately 15 minutes) with each participant: one conducted at the start of the programme, to gather background information and ask about their reasons for participating in the programme, three conducted in the course of the programme, to monitor the amount of reading, the possible changes in their EFL reading motivation and the factors influencing these changes, and one at the very end, focusing primarily on their perception of the ER experience and evaluation of its results. All the interviews were conducted in Slovene; the raw 
data collected and analysed (transcripts of audio recorded interviews and researcher's notes) were also in Slovene; only sections later used as direct quotations were translated into English. The data was analysed using inductive coding, with the coding system developed after the close examination of the gathered materials and the literature review. In the interpretation of results, extracts (direct quotations) from the raw data (i.e. interviews) were used to substantiate the findings.

After each reading, the students filled in ER reports in Slovene. Data on three topics (the amount of reading, the format of the reading material and the reader's opinion of the material) were gathered and analysed, using descriptive statistics.

\section{Results and discussion}

The presentation of the data gathered from interviews with the participants in the programme is organised according to the codes and categories that emerged from the analysis of all interviews.

\section{Change in reading intensity and attitudes towards extensive reading and EFL learning}

This section presents results gained by examining the interviews with participants and their ER reports. Participants faced some difficulty in keeping track of the number of texts read and/or the amount of time spent reading; therefore, they sometimes reported exact times (mostly when they read books), but predominantly they reported estimates, i.e. the average amount of time spent reading every day or every week. 


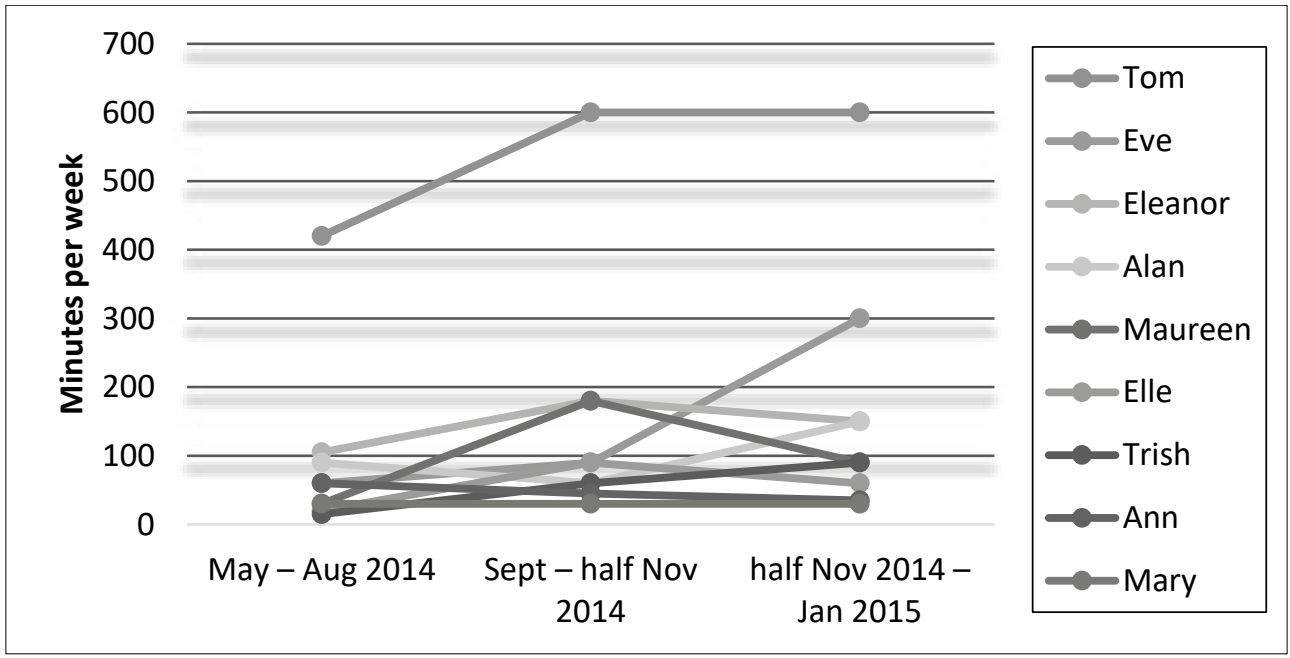

Figure 1: Estimated time (minutes / week) the participants spent reading in English

Since such estimates are bound to be subjective and not easily comparable, they were not used to make comparisons among participants in terms of their reading intensity, but to gain insight into changes in the reading intensity of each individual participant.

As shown in Figure 1, there were roughly three patterns of change in EFL reading motivation in the course of the programme: an increase in motivation (for 7 participants), a decrease in motivation (for 1 participant) and no change (for 1 participant). Erin, whose motivation decreased, is not included in the graph, since she did not report the time reading but the number of pages. Only two participants experienced a steady increase or decrease; all the others reported ups and downs in their motivation in the course of the programme, with more or less noticeable differences in the time they spent reading in English in the first 15 weeks, the middle 11 weeks or the last 11 -week period of extensive reading within the programme.

The largest section of the first 15 weeks comprised the summer holidays, when most of the participants travelled and found little time to read in English or otherwise. However, once they settled into the school rhythm and the set schedule of schoolwork and extra-curricular activities, and once we started the interviews, 
they began to read more. The second and the third part of the programme took place during the first semester of the school year. Both semesters finish with a busy few weeks of exams, presentations and assignments, which normally leave less free time for the students. There was only one participant in the programme whose reading intensity did not change but remained stable at a lower level, and that was Mary.

All the participants had at least some experience with reading in English before they decided to join the programme. They all reported reading at least a few times a month in English outside the EFL classroom, in their free time, so the reading experience within the EFL extensive reading programme was not novel to them. Moreover, all the participants reported (very) positive feelings towards reading in English (as seen in the first column of the table below); however, some spontaneously reported changes in this area as well.

As seen (Table 1), no negative impact was identified. Tom, Maureen and Trish did not refer to their reading enjoyment in the course of the programme. Since they started with positive feelings, we can assume that the programme had no affective impact on them, or they simply focused more on language and reading-related improvements. Erin reported experiencing no change in attitudes towards EFL reading, since she had liked reading even before the programme. The other six participants, however, mentioned some changes in the way they perceived EFL reading: they found EFL reading easier and more enjoyable, they wanted to read more in English, they found EFL learning easier and wanted to learn more English. The observed patterns of change in EFL reading motivation over the course of the 9-month programme confirm that reading motivation is in fact a complex and dynamic process and should be treated as such. 
Table 1: Codes for changes in attitudes towards reading in English and EFL learning

\begin{tabular}{|c|c|c|c|}
\hline & Interview 1 & Interviews 2,3 & Interviews 4,5 \\
\hline Erin & enjoys reading in English & & $\begin{array}{l}\text { No change an attitudes, } \\
\text { liked it before }\end{array}$ \\
\hline Tom & likes reading in English & & \\
\hline Eve & enjoys reading in English & & $\begin{array}{l}\text { No change in attitudes, liked } \\
\text { it before EFL learning easier }\end{array}$ \\
\hline Eleanor & enjoys reading in English & & $\begin{array}{l}\text { Want to learn more English } \\
\text { Wants to read more in } \\
\text { English }\end{array}$ \\
\hline Alan & likes reading in English & $\begin{array}{l}\text { EFL reading more } \\
\text { enjoyable }\end{array}$ & EFL reading more enjoyable \\
\hline Maureen & likes reading in English & & \\
\hline Elle & likes reading in English & $\begin{array}{l}\text { Wants to read } \\
\text { more in English }\end{array}$ & EFL reading more enjoyable \\
\hline Trish & likes reading in English & & \\
\hline Ann & likes reading in English & & $\begin{array}{l}\text { EFL reading more enjoyable } \\
\text { EFL reading easier }\end{array}$ \\
\hline Mary & likes reading in English & $\begin{array}{l}\text { EFL reading easier } \\
\text { wants to read more } \\
\text { in English }\end{array}$ & \\
\hline
\end{tabular}

Even though most of the participants were to a certain extent motivated to read in English and perceived it as something positive before the programme started, their motivation changed in very different ways. In two cases, even for the most active and proficient reader, it decreased. The interplay of different influences, dynamically changing over time, should be taken into consideration when designing reading programmes or researching reading motivation.

\section{Perceived positive influences on EFL reading motivation}

In the interviews with the participants, these codes that denote participants' perceptions about what contributed to sustaining and/or increasing their motivation to do ER were identified: sticking to the set goal, family and peer influence, home environment, ER is helpful, ER is fun and relaxing, ER is part of routine, interesting and informative materials, materials available / lack of materials in Slovene, time for reading / absence of school work, likes the language, and progress. 
In the first interview after the summer holidays, two participants reported reading more than before the programme and explained that the cause was their commitment to the programme. In Alan's words: "During summer I read more. I had hardly ever read in English before, then I joined this programme and now I read more." Additionally, all participants, except for Elle, reported virtually explicit parental encouragement and support on two levels: encouraging their reading and providing or influencing the choice of reading materials. Four participants also mentioned peer influence on their reading in English, predominantly on their choice of reading materials. The home environment was mentioned in relation to the participants' preference for reading at home as opposed to reading at school. What the participants especially pointed to was the relaxed atmosphere and freedom from time pressure, which they associated with school. According to the participants, extensive reading itself was motivating for several reasons: they found it helpful, relaxing and part of the routine. The participants joined the programme because of its perceived reading and language related benefits, and when they started noticing linguistic improvement, this positively influenced their reading motivation. Similarly, eight participants stated that the fun of reading and its relaxing effect motivated them to continue with the activity. For example, they reported: "I find it more interesting. It makes me feel good" (Alan), and "I read mostly in the evening because then I go to sleep more easily" (Trish). Two participants who managed to reach the reading target over the course of the whole programme and increase their amount of reading as they proceeded with extensive reading, attributed this to the fact that they managed to fit ER into their daily routine. Materials also proved to be a very strong factor in motivation. The participants valued interesting materials above all. In most cases, the participants reported following their interests, searching for information on topics that interested them and eventually reading about them. Especially those participants who searched for materials on the internet, reported a lack of materials in Slovene or at least finding more texts in English. As Erin explained: "Because I find more in English. It makes no sense searching in Slovene and then in English as well." Closely related to this code is the availability of materials. Especially in the first third of the programme, during summer holidays, some participants reported reading in English because the materials were simply there, easily available. Since ER was a free time activity with hardly any links to the curriculum, it depended greatly on the 
free time available to the participants. Voluntary reading competed not only with work for school but also with a number of other free time activities, socializing, etc. It was therefore not surprising that one of the most important factors influencing the amount of reading and the time dedicated to reading was absence of schoolwork or the amount of free time at the participants' disposal. Moreover, positive attitudes towards the English language were one of the most distinctly positive influences on EFL reading motivation. The participants, however, referred to English as a global lingua franca, with no explicit connection to English-speaking nations and cultures. They also associated reading in Slovene with school assignments and reading in English with their free time. Finally, almost all participants were satisfied in noticing the progress they had made, which encouraged them to read even more. The results show several factors that positively influenced EFL reading motivation. As in Nishino's (2007) and de Burgh-Hirabe's (2011) studies, perceived progress and the realisation of achievement motivated the students to read further; some also moved from graded readers (e.g. from the Reading Badge List) to authentic materials and read difficult, challenging texts (Pirih, 2017). They were motivated by the instrumental value (ER is helpful) but even more so by the intrinsic value of reading, which motivated them to pursue mastery goals (Ames, 1992), e.g. vocabulary expansion, improvement of their reading skills. An even stronger factor was the influence of family members on their reading and choice of materials, which shows the active role that parents play in their teenage children's education. The participants did not oppose this 'interference' but regarded it as acceptable, even helpful. Since they also reported favourable family attitudes towards reading, this influence confirms the findings of other researchers (Sweet, 1997; Wigfield \& Guthrie, 1997) that active readers come from families that value and encourage reading and contradicts Day and Bamford's (1998) claim that the sociocultural dimension is one of the weaker influences shaping the decision to read in a FL. Similarly, materials proved to be one of the crucial factors influencing the participants' EFL reading motivation, which fits Day and Bamford's model. The participants expressed their preference for interesting and easily available authentic reading materials, which was first found in the evaluation of the programme (Pirih 2017) and confirmed in the current research. These findings stress the need to incorporate authentic printed and online materials into foreign language ER programmes. Another strong motive for reading in EFL was the positive attitude 
towards English, which the participants closely linked to their free-time activities, and in this way perceived it as part of their own (sub)culture. Furthermore, most of them seemed to perceive the knowledge of English simply as an indispensable skill for citizens of the world, rather than a way to meet and learn about the Englishspeaking nations and cultures. Therefore, instead of referring to the Gardnerian concept of integrative motivation, which presupposes the desire to have contact with native L2 speakers and to interact with L2 cultures, this factor is better explained with Yashima's $(2002,57)$ term 'international posture', which includes a focus on foreign and international affairs, readiness to interact with intercultural partners, etc.

\section{Perceived negative influences on EFL reading motivation}

The following codes concerning perceived negative influences on the participants' motivational intensity to read extensively were identified: lack of time to read, busy with schoolwork, busy with free time activities, busy with family activities, and uninteresting materials. All participants faced a lack of time to dedicate to reading extensively. For most of them, that happened in the first part of the programme, during the school holidays, or at the end of the programme, the time busy with exams. The data suggest that there were roughly three causes that made the participants feel they lacked time for extensive reading: being busy with schoolwork, free time activities or family activities. An abundance of schoolwork was a problem for all the participants at least once during the programme. It turned out to be the strongest negative influence on their reading motivation in that time. Eve explained: "I read a book I borrowed from your library, about Bridget Jones. I managed to read about half of it. Then things for school started piling up, so I quit for a while." Similarly, four participants mentioned their extra-curricular activities (athletics, gymnastics, violin) and how much time they invested in these, which left less time for reading. Especially in the initial phase of the programme, i.e. during the school holidays, the participants who reported reading less in the preceding weeks said that the reason was family vacations and other family activities. Because of the voluntary nature of the programme and free choice of materials, only two participants reported having problems with uninteresting materials (not finishing books they found less interesting). The participants probably left more texts unread, however; 
leaving a book unread is more memorable than changing to another website because it is not interesting. As in Nishino's (2007) and de Burgh-Hirabe's (2011) studies, among the most influential factors that shaped the course of EFL reading motivation of the participants were external demands, predominantly schoolrelated, and distractions connected to the participants' extra-curricular and family activities. For most of them, these factors negatively influenced their reading motivation, with some exceptions. According to data from the interviews, extracurricular activities had only a limited effect over limited periods of time, while schoolwork had a stronger impact. Even though the participants recognised the instrumental value of ER, most of them saw it as a time-consuming activity in the periods when time was invested in intensive schoolwork. If ER had been an integral part of the school curriculum with an assigned time, this negative influence might have had a weaker effect. However, this would have also limited the readers' autonomy in choosing the time and place of reading, which the participants of this ER programme valued (Pirih, 2017).

\section{Conclusion}

Despite its limitations (e.g. a relatively small, single-school sample of participants), the present study provides valuable insight into the dynamics of the EFL reading motivation of Slovene primary school pupils and the factors causing motivational changes. It was conducted within a 9-month pilot extensive reading programme, implemented by the researcher to give the participants an experience of extensive reading and test its pedagogical potential. A previous study (Pirih, 2017) has already proven that the ER approach is an effective and motivating way to teaching FL reading for primary school students. The findings of the current research confirm that EFL reading motivation is a complex and dynamic process fuelled by numerous influences that need to be considered when designing reading programmes or researching reading motivation.

The strongest factors shaping EFL reading motivation among the participants were the reading materials, the influence of family members, positive attitudes towards English, and external demands. One of the most important ingredients in successful extensive reading is clearly a selection of reading materials that goes beyond graded 
readers and other printed formats. The participants' reading preferences suggest that it is of utmost importance to include online materials and authentic texts of other formats into extensive reading programmes and to give the participants autonomy in choosing what they want to read. Family influence was also recognised as a strong factor, with a powerful effect on the participants' reading, which suggests the need for further research into parental attitudes towards voluntary reading in FL and their reading behaviour. Additionally, the results show that for this age group, English is no longer only the official language of English-speaking countries and thus closely connected to the culture of English-speaking nations, but a lingua franca and thus to some extent a neutral and culture-free tool for communication with the whole world. Moreover, it is perceived as an integral part of their free time and their own (sub)culture. Finally, the results show that external demands and distractions result in a lack of time and thus negatively influence reading motivation. Although the participants expressed a strong preference for reading in the home environment with no time restraints, it might prove effective to include extensive reading into the school curriculum as well, for example as an uninterrupted sustained silent reading activity within EFL lessons, which might offer additional reading time to students and thus reduce the negative impact of external demands and distractions. In Slovenia, extensive reading is an approach less commonly taken, which has resulted in a lack of experience with it. Therefore, further research is needed to study the influence of extensive reading. Moreover, small-scale action research projects by Slovene teachers and professors exploring different ways of implementing extensive reading and measuring its influence would be fruitful.

\section{References}

Aiello, J. (2016). Read On! Evaluation Study: Academic Report. Oxford: Oxford University Press.

Alderson, J. C., \& Urquhart, A. H. (1984). Reading in a foreign language. Longman Pub Group.

Ames, C. (1992). Classrooms: Goals, structures, and student motivation. Journal of Educational Psychology, 84 (3), pp. 261-271.

Baker, L., \& Wigfield, A. (1999). Dimensions of children's motivation for reading and their relations to reading activity and reading achievement. Reading Research Quarterly, 34(4), pp. 452-477.

Bandura, A. (1993). Perceived self-efficacy in cognitive development and functioning. Educational Psychologist, 28, pp. 117-148.

Bratož, S., \& Žefran, M. (2018). Systematicity in Foreign Language Classroom Communication. The New Educational Review, 53(3), pp. 71-84.

Briggs, J. G., \& Walter, C. (2016). Read On! Extensive Reading and Young Second Language Learners' Motivation and Attitudes (unpublished report). Retrieved from https://www.research- 
gate.net/publication/301453032_Read_On_Extensive_Reading_and_Young_Second_La nguage_Learners'_Motivation_and_Attitudes (Accessed: 25 th July 2019.)

Day, R., \& Bamford, J. (1998). Extensive reading in the second language classroom. Cambridge, UK: Cambridge University Press.

Day, R., \& Bamford, J. (2002). Top ten principles for teaching extensive reading. Reading in a Foreign Language, 14 (2), pp. 136-141. Retrieved from http://nflrc.hawaii.edu/rfl/October2002/ (Accessed: 24th July 2019.)

de Burgh-Hirabe, R. (2011). Extensive reading and L2 reading motivation in Japanese as a foreign language: a case study of New Zealand high school students (Doctoral dissertation). Retrieved from Otago University Research Archive (2011-05-31T23:43:56Z). (Accessed: 24th July 2019.)

de Burgh-Hirabe, R., \& Feryok, A. (2013). A model of motivation for extensive reading in Japanese as a foreign language. Reading in a Foreign Language, 25(1), 72-93. Retrieved from http://nflrc.hawaii.edu/rfl/April2013/articles/deburgh.pdf (Accessed: 24th July 2019.)

Deci, E. L., \& Ryan, R. M. (1985). Intrinsic motivation and self-determination in buman behaviour. New York: Plenum Press.

Deci, E. L., \& Ryan, R. M. (1987). The support of autonomy and the control of behaviour. Journal of Personality and Social Psychology, 53(6), pp. 1024-1037.

de Morgado, N. (2009). Extensive reading: Students' performance and perception. The Reading Matrix, 9, pp. 31-43. http:/ / citeseerx.ist.psu.edu/viewdoc/download?doi=10.1.1.539.7650\&rep $=$ rep1\&type $=$ pdf (Accessed: $25^{\text {th }}$ July 2019.)

Dickinson, L. (1995). Autonomy and motivation a literature review. System, 23(2), pp. 165-174. Retrieved from http://www.sciencedirect.com/science/article/pii/0346251X95000055 (Accessed: 25th July 2019.)

Dörnyei, Z., \& Ottó, I. (1998). Motivation in action: A process model of L2 motivation. Working Papers in Applied Linguistics, 4, pp. 43-69.

Eccles, J. S., Adler, T. F., Futterman, R., Goff, S. B., Kaezala, C. M., Meece, J., \& Midgley, C. (1983). Expectancies, values and academic behaviour. In J. T. Spence (Ed.), Achievement and achievement motives (pp. 75-146). San Francisco: W. H. Freeman.

Eccles, J. S., \& Wigfield, A. (1995). In the mind of the actor: the structure of adolescents' achievement task values and expectancy-related beliefs. Personality and Social Psychology Bulletin, 21, pp. 215-225.

Fujita, K., \& Noro, T. (2009). The effects of 10-minute extensive reading on the reading speed, comprehension and motivation of Japanese high school EFL learners. Annual Review of English Language Education in Japan, 20, pp. 21-30.

Grabe, W., \& Stoller, F. L. (2002). Teaching and researching reading. New York: Pearson Education.

Guthrie, J. T., \& Wigfield, A. (1997). Reading engagement: a rationale for theory and teaching. In J. T. Guthrie, \& A. Wigfield (Eds.), Reading engagement: motivating readers through integrated instruction (pp. 1-12). Newark: IRA.

Hidi, S., \& Renninger, A. (2006). The Four-Phase Model of Interest Development. Educational Psychologist, 41(2), pp. 111-127. Retrieved from http:// citeseerx.ist.psu.edu/viewdoc/download?doi=10.1.1.521.6334\&rep $=$ rep1\&type $=$ pdf (Accessed: $25^{\text {th }}$ July 2019.)

Judge, P. B. (2011). Driven to read: Enthusiastic readers in a Japanese high school's extensive reading programme. Reading in a Foreign Language, 23(2), pp. 161-186. Retrieved from http://files.eric.ed.gov/fulltext/EJ943535.pdf (Accessed: 24th July 2019.)

Krashen, S. D. (2011). Free Voluntary Reading. Santa Barbara: ABC-CLIO.

Lake, J. (2014). Curious readers and interesting reads: Developing a positive L2 reading self and motivation through extensive reading. Journal of Extensive Reading, 2, pp. 13-27.

Leung, C. Y. (2002). Extensive Reading and Language Learning: A Diary Study of a Beginning Learner of Japanese. Reading in a Foreign Language, 14(1), pp. 66-81. 
Lien, H.Y. (2010). EFL College learners'perceptions of self-selected materials for extensive reading. The English Teacher, 39, pp. 194-204.

Mangen, A., \& Van der Weel, A. (2016). The evolution of reading in the age of digitisation: an integrative framework for reading research. Literacy, 50(3), pp. 116-124.

Mangen, A., Walgermo, B. R.,\& Brønnick, K. (2013). Reading linear texts on paper versus computer screen: Effects on reading comprehension. International journal of educational research, 58, 6168.

Mason, B., \& Krashen, S. (1997). Extensive reading in English as a foreign language. System, 25(1), 91-102. Retrieved from http://www.sciencedirect.com/science/article/pii/S03462$51 X 96000632$ (Accessed: 23 ${ }^{\text {rd }}$ July 2019.)

McCracken, R. A. (1971). Initiating sustained silent reading. Journal of Reading, 14 (8), pp. 521-524. Retrieved from http://www.jstor.org/stable/40009700 (Accessed: 20th April 2014.)

Milliner, B., \& Cote, T. (2015). One year of extensive reading on mobile devices: Engagement and impressions. In F. Helm, L. Bradley, M. Guarda, \& S. Thouësny (Eds.), Critical CALL Proceedings of the 2015 EUROCALL Conference (pp. 404-409). Padova, Italy: Researchpublishing.net.

Mori, S. (2002). Redefining Motivation to Read in a Foreign Language. Reading in a Foreign Language, 14(2). Retrieved from http://nflrc.hawaii.edu/rfl/October2002/mori/mori.html (Accessed: 23rd July 2019.)

Nishino, T. (2007). Beginning to read extensively: A case study with Mako and Fumi. Reading in a Foreign Language, 19 (2). Retrieved from https://files.eric.ed.gov/fulltext/EJ777744.pdf (Accessed: 23 $3^{\text {rd }}$ July 2019.)

Palmer, H. (1968). The scientific study and teaching of languages. Oxford: Oxford University Press.

Pečjak, S., \& Gradišar, A. (2012). Bralne učne strategije. Ljubljana: Zavod Republike Slovenije za šolstvo.

Pečjak, S., Bucik, N., Gradišar, A., \& Peklaj, C. (2006). Bralna motivacija v šoli: merjenje in razvijanje. Ljubljana: Zavod Republike Slovenije za šolstvo.

Pečjak, S., \& Košir, K. (2004). Pupils' reading motivation and teachers' activities for enhancing it. Review of Psychology, 11(1-2), pp. 11-24.

Pečjak, S., \& Peklaj, C. (2006). Dimensions of reading motivation and reading achievement in $3^{\text {rd }}$ and $7^{\text {th }}$ grade students. Studia Psychologica, 48(1), pp. 11-29.

Pirih, A. (2015). Who says they don't read? Slovene elementary school students' reading motivation in EFL. Journal of Elementary Education, 8 (1-2), pp. 113-132.

Pirih, A. (2017). Extensive reading in EFL for young Slovene teenagers : an evaluation study. In S. Bratož (Ed.), Razsežnosti sodobnih učnih okolij = Dimensions of contemporary learning environments (pp. 285-299). Koper: Založba Univerze na Primorskem.

Robb, T. N., \& Susser, B. (1990). EFL Extensive Reading Instruction: Research and Procedure. JALT Journal, 12 (2). Retrieved from http:/ /www.cc.kyoto-su.ac.jp/ trobb/sussrobb.html (Accessed: 23rd July 2019.)

Ryan, R. M., \& Deci, E. L. (2000). Intrinsic and Extrinsic Motivations: Classic Definitions and New Directions. Contemporary Educational Psychology, 25, pp. 54-67. Retrieved from https://mmrg.pbworks.com/f/Ryan,+Deci+00.pdf (Accessed: 24th July 2019.)

Sani, A. M., \& Zain, Z. (2011). Relating Adolescents' Second Language Reading Attitudes, Self Efficacy For Reading, and Reading Ability in a Non-Supportive ESL Setting. The Reading Matrix, 1 (3), pp. 243-254.

Silva, J. P. (2009). Extensive Reading through the Internet: Is it Worth the While? International Journal of English Studies, 9(2), pp. 81-96. https://revistas.um.es/ijes/article/view/90761/87561 (Accessed: 25 ${ }^{\text {th }}$ July 2019.) 
Sweet, A. P. (1997). Teacher perceptions of student motivation and their relation to literacy learning. In J. Guthrie, \& A. Wigfield (Eds.), Reading engagement: motivating readers through integrated instruction (pp. 86-101). Newark, Delaware: Reading Association.

Takase, A. (2007). Japanese high school students' motivation for extensive L2 reading. Reading in a Foreign Language, 19(1). Retrieved from http://nflrc.hawaii.edu/rfl/april2007/takase/takase.html (Accessed: 23 $3^{\text {rd }}$ July 2019.)

Takase, A. (2016). Paper book or ebook? First trial of XReading. The Journal of the Extensive Reading SIG of the Japan Association for Language Teaching, 9(2). Retrieved from http://hosted.jalt.org/er/sites/jalt.org.er/files/ERJ/erj_issue_9.2.pdf (Accessed: 24 ${ }^{\text {th }}$ July 2019.)

Walker, R. J. (2017). Screen versus paper: Perceptions of screen-based reading versus paper-based reading in supplementary extensive reading (SER) programmes. In G. Brooks (Ed.), The 2016 PanSIG Journal (pp. 348-360). Tokyo: JALT.

Wigfield, A. (1997). Children's motivations for reading and reading engagement. In J. Guthrie, \& A. Wigfield (Eds.), Reading engagement: motivating readers through integrated instruction (pp. 14-33). Newark, Delaware: Reading Association.

Wigfield, A., \& Guthrie, J. T. (1997). Relations of children's motivation for reading to the amount and breath of their reading. Journal of Educational Psychology, 89(3), pp. 420-432.

Yamashita, J. (2004). Reading attitudes in L1 and L2, and their influence on L2 extensive reading. Reading in a Foreign Language, 16(1), pp. 1-19. Retrieved from http://nflrc.hawaii.edu/rfl/April2004/yamashita/yamashita.html (Accessed: 24th July 2019.)

Yashima, T. (2002). Willingness to Communicate in a Second Language: The Japanese EFL Context. The Modern Language Journal, 86(1), pp. 54-66.

\section{Author}

\section{Anja Pirih, PhD}

Lecture, University of primorska, Faculty of Humanities, Titov trg 5, 6000 Koper, Slovenia, e-mail: anja.pirih@fhs.upr.si

Lektorica, Univerza na Primorskem, Fakulteta za humanistične študije. Titorv trg 5, 6000 Koper, epošta: anja.pirih@fhs.upr.si 